\title{
THE NEW PROVINCIAL ARCHIVES OF QUEBEC
}

FVERY student of history knows that an ideal Archives E Branch should be able and willing to guide him toward the truth in these four essential ways: first, by having as much as possible of the original evidence in its original form; secondly, by having authentic copies of the most important originals which are kept elsewhere; thirdly, by having a descriptive catalogue of all the original evidence on the special subject with which the Branch is concerned; and fourthly, by having a guidebook to show the archival connections between this special subject and the greater whole of which it forms a correlated part.

That the province of Quebec has not reached such an ideal is no great matter for surprise; and the more the obstacles are studied the less the surprise will be. But that this "Ancient" and "Historic" province, this "Cradle of New France", this "Heart of Old Canada," should only now be forming its first regular Provincial Archives is something that does seem to need an explanation. The present article is really an explanation from beginning to end. Yet we might as well understand at once that Quebec is a follower instead of a leader among her sister provinces on account not of her poverty but her embarrassing wealth. The archives of what was once the whole of Canada, and of what must always be its most historic part, are not only greater in bulk and more complex in kind than those of other provinces but by far the most intimately correlated with those of the Dominion. Moreover, many large and well-arranged collections exist in Montreal and Quebec, each serving its own special purpose so well that the need of a unified provincial reference scheme has been the less acutely felt. It is, however, time that the many and very different parts (though each retaining its complete autonomy) should be correlated by means of some simple scheme of handy reference. It is also time that the province and the Dominion should each control an entirely separate, though likewise correlated, sphere of influence.

The first regular Provincial Archives Branch was established at Quebec in September, 1920. But, like the Public Archives at Ottawa, it has a history behind it. Each has passed through 
a neglected infancy and a rather troubled childhood before attaining man's estate. The Dominion Archives date from 1872, when Dr. Brymner issued his first report. For the next thirty years he worked devotedly with woefully insufficient means and absurdly inadequate accommodation. Many a student not yet old can remember the sort of converted furnace room in which priceless documents had to be stacked like so much fire wood; and many who are still comparatively young can remember the grubby little rooms in which the nation's archives were afterwards shoved aside to be out of the way. At last, in 1904, a happy conjunction of the four proper men took place, with the magnificent result which everyone can see at Ottawa to-day. Lord Minto and Sir Wilfrid Laurier took the keenest personal interest in making the Canadian Public Archives what they ought to be. The Hon. Sidney Fisher, perceiving the new importance of the Archives, took them under his administrative wing. And in Dr. Doughty both Lord Minto and Sir Wilfrid found a man who is all the better Archivist for being so very much more.

By another happy conjunction these four men were particularly keen about the archives connected with Quebec. In a letter marked Private, written from the Viceregal Lodge at Simla five years after he had left Canada for good, Lord Minto said: "How I wish I could have been present at the Tercentenary! There never was such a place for such a pageant as Qu'ebec: so full of old memories; and the very atmosphere seeming to take one back to the Chien d'Or and all the surroundings of that time. There is a fascination about it all which I have never met anywhere else. I hope perllaps some day I may wander back as a quiet tourist." Sir Wilfrid Laurier and Mr. Fisher both represented Quebec constituencies; and this was Sir Wilfrid's answer when asked to join the Historic Landmarks Association, which was founded at a meeting of the Royal Society in Ottawa, but according to suggestions from Quebec: "It is a matter of absolute rule with me not to belong to any organization of any kind, however meritorious the object may be; but in this case I think I will make an exception." Those who were behind the scenes know that Lord Minto's and Sir Wilfrid's words were no mere expression of the polite interest which public men feel bound to show on perfunctory occasions, but the genuine expression of what they really thought and felt.

Dr. Doughty's inspiring connection with the Dominion Archives is so well known on both sides of the water and the line 
that his equally long connection with Quebec is apt to be forgotten. Yet, it was during his stay there that he and Dr. G. W. Parmelee, the well-known Quebec educationist, produced their six splendid volumes of text and archives on The Siege of Quebec. It was also Dr. Doughty who edited The King's Book of Quebec, which formed the Viceregal souvenir of Tercentennial Quebec. And it is under Dr. Doughty's fostering care that the Quebec part of the Dominion Archives has become a source of original evidence without which no verdict can even be considered on Canadian history as a whole.

Dr. Doughty, again, was the chief whose Quebec specialist, Mr. Pierre Georges Roy, has now most worthily become the new Provincial Archivist. This is another fact that augurs well for the correlations between the province and Dominion. So, too, are the facts that Sir Charles Fitzpatrick, the Hon. L. A. Taschereau, and the Hon. Athanase David are respectively the lieutenant-governor, the prime minister, and the secretary under whom the new Provincial Archives begin their promising career. The "Fitzpatrick Edition" of The Siege of Quebec implied far more than a compliment to the new Chief Justice of Canada; for it associated with the city the name of a native citizen who knows and loves her history through and through, and who, by his great experience of Canadian, imperial, and international affairs, can also see how city and province are connected with things more complex than themselves. Mr. David, the enlightened minister to whose department the Archives Branch belongs, comes from Montreal, and is intimately acquainted with the intellectual life of the greatest city in the province and Dominion. Mr. Taschereau, like Sir Wilfrid Laurier, is a prime minister who zealously promotes everything that enhances the practical value of a proper Archives Branch. $\mathrm{He}$ is, indeed, the actual founder of the present system. Bon chien chasse de race: and a personal interest in archives should come naturally to $\mathrm{Mr}$. Taschereau, whose family has been so long and intimately connected with the making of Canadian history. From the provincial prime minister of the twentieth century the Taschereaus go back to the first Canadian cardinal of the nineteenth and to the French-Canadian officer who mustered his compatriots on the Esplanade at Quebec in the eighteenth century to assist Carleton against Montgomery and Arnold. In the seventeenth we find "Gabriel Taschereau, sieur de Baudry et de Linière, maître des eaux et forêts en Touraine"-ce doux pays de la Touraine, which Belleforest so aptly called le jardin de France 
et le Plaisir des Roys; while in 1492, the year this New World was discovered, "Pierre Taschereau, marchand de drap de soie," was an alderman of Tours.

French-Canadian genealogy brings us into immediate touch with Mr. Pierre Georges Roy, new as provincial archivist, and in the prime of life so far as age is concerned, but a very old hand at archival research. We shall presently meet him as the indefatigable and highly expert compiler of those nine volumes of Archives de la Province de Québec which we shall review at the end of this article. Here we need only remind our readers that he has already edited twenty-seven annual volumes of his wellknown and highly valued Bulletin des Recherches Historiques, and that, by means of this periodical and his further experience as a French-Canadian specialist in the Dominion Archives, he comes to his present labour of love fully equipped for the great foundational task which we shall explain later on. His appointment is, in certain ways, of even more importance to the province than Dr. Doughty's was to the Dominion; because the new provincial system differs moire widely from the old than new from old in the case of the Dominion. There was a centralized Dominion Archives Branch at Ottawa for thirty-two yeans before' Dr. Doughty took it over. But, in any proper sense of the words, there was no regular centralized Provincial Archives Branch before Mr. Roy's appointment in September, 1920. Mr. Eudore Evanturel served the province with devoted zeal for thirty years. But he was never given the means of forming a real Provincial Brañch. From his time back to Confederation a deputy registrar looked after such archives as the government deemed sufficiently provincial anid otherwise neglected for his care.

By this time the hypercritic who has read Candide, and who has also seen the single fire-proof room in which the Quebec Provincial Archives are at present stored, will doubtless be inclined to, quote from its famous opening chapter: M. le baron de Thunderten-tronckh était un des plus puissants seigneurs de la Westphalie; car son château avait une porte et des fenêtres. But may I ask this hypercritic to remember that, as he will presently see for himself, Mr. Roy's new Archives Branch is only the well and truly laid foundation of what it will yet take many years to build, and that even the building itself is not designed to be more in correlation 
with the whole vast mass of provincial archives in different hands or places, than is the axis to a globe?

A moment's consideration of the many different things the province of Quebec has been throughout the last three hundred years must convince every student of the immense complexity of the archives recording its multiform activities, and of the impossibility, as well as the inadvisability, of trying to concentrate them under any one official authority, muich less in any one official place. The most, and perhaps the best, that can be done is to extend the system of Mr. Roy's official Inventaires, and combine it with mere reference catalogues in the case of privately owned archives which have good special catalogues, so that eventually a student will be able to find in the Provincial Archives Branch at Quebec either the original evidence itself or a ready reference to the exact place where it can be found elsewhere.

From New France to New Quebec this province has been a dozen different things; that is, if the four chief ecclesiastical differences are added to the eight which happened under civil rule; and of course every one of these twelve changes has left its mark on provincial and Dominion archives.

(1.) 1608-1763. Quebec was Canada-in the old restricted sense of the word Canada-throughout the French régime. Louisiana and Acadia differed from Canada, so far as civil government was concerned, in much the same way as one of the contemporary British American colonies differed from another. Race, language, war, and, above all, the church, were the general bonds of union. But in administration, and in certain ways of daily life as well, Acadians, Louisianans and Canadians thought and spoke of themselves as different varieties of the same specific stock. This sense of difference is not yet extinct even in confederated Canada; for a Cape Breton fisherman will talk of going to Canada, if he sails for Montreal, in almost the same way as Greeks and Russians still talk of going to Europe when they take train for France.

(2.) 1763-1774. Quebec continued to be Canada during the first eleven years of British rule. Carver's New Map of the Province of Quebec according to the Royal Proclamation of the 7th of October, ${ }^{17} 63$ (reprinted in Doughty and Shortt's Constitutional Documents, published by the Dominion Archives in 1907), shows the boundaries to have been the following: North: from the S. E. extremity of Lake Nipissing, through Lake St. John, and thence to the upper reaches of the St. John River, 
which enters the estuary of the St. Lawrence opposite the west end of Anticosti. Labrador, Anticosti, and the Magdalens belonged to Newfoundland. The southern boundary (allowing for the disputes that lasted till the Ashburton Treaty of 1842) was much the same as it is to-day. But the western line, by crossing the St. Lawrence at the head of Lake St. Francis and making straight for Lake Nipissing, took in the whole west bank of the Ottawa.

(3.) 1774-1783. A portentous change was effected by the famous Quebec Act of 1774. This Magna Charta of the FrenchCanadian clergy and seigniorial class not only roused fierce debates in the imperial parliament, but was regarded by the American revolutionists as the final clincher of what they called the "Five Intolerable Acts," because it barred their way beyond the Mississippi. It took from Newfoundland the Atlantic coast of Labrador, the Magdalens, and Anticosti. It likewise added to Quebec practically all but the new north part of what is now Ontario. And it included everything between the Mississippi and Ohio, that is to say, the modern states of Ohio, Indiana, Michigan, Illinois, Wisconsin, and part of Minnesota.

(4.) 1783-1791. With the recognition of the United States the province naturally lost all this country between the Mississippi, the Ohio, and the Lakes.

(5.) 1791-1840. When the U. E. Loyalists had settled down the province was divided into the Upper and Lower Canada which have persisted to the present day as Ontario and Quebec. Moreover the beginning of parliaments introduced another and an altogether new element into provincial archives.

(6.) 1840-1867. The Act of Union again made Upper and Lower Canada a legislative whole, with one parliament instead of two, thus effecting an important change in some of the governmental archives. But, as before and afterwards, the FrenchCanadian ways of life developed along their own lines within what is now Quebec.

(7.) 1867-1912. Confederation, and the subsequent concentration in Ottawa of all that concerns Canada as a whole, naturally raised the question we shall presently discuss about the proper line of demarcation between the provincial and Dominion archives.

(8.) 1912-1921. When New Quebec was added to the existing province, under the statesmanlike administration of Sir Lomer Gouin, the Provincial Archives became entitled to all the public archives of the Labrador peninsula, except those concerned with 
Dominion matters or with whatever part of the Atlantic coast may be adjudged to Newfoundland after the final boundary is settled.

To these eight different Quebecs in the eyes of the law, we must add four in the eyes of the church.

(1.) Up till 1783 Quebec was the diocesan headquarters of all the French-speaking Roman Catholics in the whole of North America. Even now, if a student of ecclesiastical history wishes to see the original evidence about any question of diocesan importance concerning a pre-Revolution church or mission down in New Orleans he must come to find it in the Cardinal's Palace at Quebec. Neither the cession of Louisiana to Spain in 1762 nor that of Canada to Great Britain in 1763 ended the diocesan connection of Quebec with the whole country between the Mississippi and the Rocky Mountains. Nor did the re-cession of Louisiana by Spain to France in 1800 cause a reconnection during the three years that preceded the Louisiana Purchase. The final disconnection came in 1783, after Great Britain's recognition of the United States. (2.) Thenceforth the Bishop of Quebec exercised authority over no more than what remained of British North America. (3.) As new bishoprics were gradulally established in other parts of British North America, and in the province of Quebec itself, the old diocesan boundaries gradually shrank until they assumed (4) their present archidiocesan limits. Thus, in Church and State together, Quebec has been twelve different things during the last three hundred years.

Each change is of course reflected in provincial archives; and the whole question is further complicated by the essential differences which have developed between the separate jurisdictions of the province and Dominion. The fact is that no precise line of demarcation can be drawn between provincial and Dominion archives. Nor, as it most fortunately happens, is there any pressing need to draw ane. The entente cordiale between the two Branches is so complete that each can supplement the other as the occasion may require, and in these days of rapid facsimile reproductions the mutual exchange of documents is a cheap and easy matter.

In a general sense it may be said that the line of demarcation between the two kinds of archives should correspond with the jurisdictional differentiation between the province and Dominion. Whatever concerns Canada as a whole, and more especially her relations with the Empire and the world at large, should be 
substantiated by Dominion archives. Whatever concerns Quebec alone, or even most of all, should be provincial. The French régime and all forms of French-Canadian life are naturally of special interest to Quebec, even when concerned with what may have happened beyond the exact provincial boundaries, simply because Quebec is, par excellence, the French-Canadian province. Therefore, to make this long and complex story short, the new Quebec Provincial Archives under Mr. Roy are concerned not only with what is officially provincial but with all things French and French-Canadian too.

War, however, is a more or less modified exception, because war has always been an all-Canadian, imperial, or international affair, no matter how much or little the French or French-Canadians were concerned. Yet it is better to err on the side of inclusion when doubtful cases are at issue, especially in what concerns the personnel. Who would exclude Mr. Roy's archival biographies of Les Officiers d'Etat-Major des Gouvernements de Québec, Montréal, et Trois Rivières sous le Régime Français, especially in view of the many civil functions these officers performed?

Coming to the field of work that lies before the new Branch at Quebec, and beginning with all things officially provincial, it is obviou's that government documents claim first attention, whatever period is concerned. Going back to origins, a student wishing to ground himself thoroughly should get his bearings from the compilation made by the late Mr. J. Edmond Roy (Mr. P. G. Roy's brother) out of the accumulated researches of the best French archivists, and published by the Dominion Archives in 1911 as a Rapport sur les Archives de France relatives a l'Histoire $d u$ Canada. This portly volume, of nearly 1,100 pages, not only gives much direct information but opens the way to further original evidence of every useful kind. Some of the early government documents preserved in Canada itself and catalogued by Mr. P. G. Roy form the subject of the review with which we close this article. But these are only a few of even those concerned with the French régime alone. The entire activities of all governments down to the present day should have their appropriate documentation; and, as a general rule, the moment any important document ceases to be an active office paper it should become an archive.

To take a single concrete case in which archives and office papers are happily combined in fire-proof buildings and under expert care; (though not a case which differs from what is done 
in other provinces). The Attorney-General of Quebec presides over twenty-three judicial districts, each with its own prothonotary, who assembles, inspects, and files away all notarial acts as well as other legal documents. The fact that copies of all parish registers must also be sent in to him connects Church archives with the state in this particular way. But not even copies of other Church archives have to be sent in; and all originals of course remain Church property. This is equally true, whatever form of religion is concerned. But, for the moment, we are speaking of French-Canadian Roman Catholics alone.

Before returning to archives which are the property of the provincial government we should take a glance at some nongovernmental archives; so as to understand the great value and variety of all the archives relating to Quebec.

Without a knowledge of the Church archives no one can understand the innermost recesses of French-Canadian life. And these archives are less known than even students think. For instance, everyone knows Les Relations des Jésuites; but how many know that the originals of these missionary comptes rendus form only a very small part of the great mass of Jesuit archives in the Collège de Ste. Marie in Montreal, and that very little besides the Relations has ever been published at all? The Montreal Sulpicians, again, have enormous masses of unpublished archives. And, as we have seen already, the archdiocese of Quebec possesses archives of a still more varied kind. Add the great collections accumulated by long-established orders, like the Ursulines and Hospitalières; by orders prominent in earlier days, like the Récollets; by orders of later times in Canada, like the Oblats and Eudistes; and by the many orders of still more recent arrival in the province of Quebec; and add to all these again the vast accumulations of diocesan and parochial archives: and the student will begin to see what fields of research there are which must be worked by those who would understand the French-Canadians from an inside point of view.

Except for the parish registers, strictly so-called, the government has nothing to do with religious archives-neither these nor any others; and there are some others of peculiar interest, Anglican, Presbyterian, and the rest. Nor, by the way, is English the only other language in which archival records may be found: Indian and Gaelic are two more. There once was a militia battalion with all four different native tongues in which the detail 
had to be explained; though the actual words of command were given in English only.

Counties, as such, play little part in the provincial life of Quebec: nothing, for instance, like the part they play in Nova Scotia, where some Bluenoses occasionally regard other Bluenoses almost as one military borderer is apt to regard another, all the world over, if the frontier runs between them. But certain towns have had a long municipal history of their own; and we must not forget that Montreal and Three Rivers were once little capitals of (if we may coin the word) Lieutenant-Governments, and that Quebec has been a sub-provincial and super-provincial capital as well as the simply provincial capital it has again become.

Seigniories have been another source from which important archives have grown up independently of government ownership, though in some ways more intimately connected with the government than even the Church was, in spite of all the State's continued care for her "accustomed dues". The seigniorial system flourished for nearly two centuries; and what archives it produced as a whole may be inferred from the six volumes published by Mr. J. Edmond Roy on the single Seigneurie de Lauzon. There are few Canadian families whose private papers have anything like the national interest of those examined by Historical Manuscript Commissions in Canada's two mother countries. But there are some family records, as well as individual collections, which should at least be noted for reference in connection with the Provincial Archives.

Business done more or less within provincial limits must also have produced some interesting archives-mostly, no doubt, destroyed as hopelessly "back-numbered"; or perhaps surviving only in emasculated government reports and the files of forgotten periodicals. Take fur and the fur-lords of Montreal; or the wonderful activity of the timber trade and ship-yards at Quebec; or the newer provincial interests in mines, manufactures, and the sporting side of fish and game; or the perennial interests of the forest and the farm: there must be some archives still ungleaned.

Or take societies connected with different forms of racepatriotism, or those of a more or less "learned" kind. There once was an Agricultural Society whose meetings were attended by Carleton. Montreal has its Société Historique, and Château de Ramezay as the headquarters of its Numismatic and Antiquarian Society. Quebec city has what seems to be the senior of all the learned societies in the British Empire overseas-the 
Literary and Historical Society, which will celebrate its centenary in 1924. All these, and a few more, can make some contribution to provincial archives, at all events by supplying references to what they have in their possession.

Finally, take such archives as originate in English-not that they otherwise form a separate class or that many of them are not included in the classes mentioned already. The arrival of the U. E. Loyalists, the establishment of the Eastern Townships, the records of garrison life on the non-official side, the documents of various religious bodies, are only some of the activities of Englishspeaking people in the province of Quebec that should find substantiation in provincial archives.

This rapid glance at the archives of Quebec will give some idea of the need for making a general survey of all the records that exist, no matter whether owned by the provincial government or in other hands. Such a survey would have little trouble in obtaining the proper information in the case of archives belonging to the government. But it would take a good deal of time, more trouble, and most skill to discover and describe everything of any real importance that belongs to others. Moreover, some tact would be required, in certain cases, to reassure suspicious owners that the government harboured no ulterior designs against their property and that, so far as getting the mere information was concerned, the members of the government survey were only asking as a favour what they could not claim as a right. Of course, private owners (using the word "private" to include everything not belonging, as of right, to the provincial government) would have nothing to lose and, in most cases, something to gain by having their archives entered in a general catalogue; for this all-inclusive guide would not only show official recognition of their ownership (thus furnishing a universal system of identification in case of loss), but would also save them the trouble of explaining to enquirers what they had as well as what they did not have.

Moreover, to be able to find in the Provincial Archives Branch the proper clues to everything elsewhere as well as on the spot is a consummation devoutly to be wished, for an even higher reason than convenience of research; because whatever brings the truth about the province into living touch with the correlated truth about the Dominion and both its Mother Countries must help all true historians to restrict the area of darkness, prejudice, and misunderstanding in which so many scribbling partizans can still 
mislead their readers. There are three stages in the study and writing of history. The first is that of little archives and much prejudice. The second is that of more archives; but not enough to lighten truth and blacken prejudice. The third is that in which the original evidence of the archives is strong enough to convince all but those who shut their eyes.

The discussion of history and histories, however, is going rather far afield to-day. So we shall return to the present new Provincial Archives Branch, its very able Archivist, and his special line of work. Mr. P. G. Roy's own words will best explain his first great aim. "Sous le titre collectif d'Archives de la Province de Québec nous espérons inventorier, d'ici à une dizaine d'années, les principaux dépôts d'archives de la province de Québec. Les deux premières séries de cette publication seront entièrement consacrées aux Archives Provinciales (Palais législatif) et aux Archives Judiciaires de Québec (Palais de Justice)." Four years ago Mr. Roy thought twenty-two volumes would suffice for these inventories; but, as what he had thought would fill the first six has really filled nine, it seems certain that thirty at least will be required for the whole. These thirty volumes or so are only the descriptive catalogues of two collections of government archives in the city of Quebec. To catalogue, in the same descriptive way, the rest of the government archives in the province at large, and all the privately owned archives as well, would fill at least three hundred volumes, if not a great many more. There is, however, no need for this, provided that the Provincial Archives Branch has a very condensed general catalogue giving the proper references to the special catalogues of private collections. The Church archives now in the Cardinal's Palace at Quebec alone fill more than 15,000 dossiers. But Monseigneur Gosselin, the accomplished veteran Archivist of Laval University, has them all ready for reference on the spot. And so with many other private Church and lay collections; though it must be borne in mind that nearly all these catalogues exist in manuscript only.

Again, it must be remembered that only the originals of many archives exist. When they are really important they should be facsimiled by and for the new Branch: and this speedily; for some are in danger of fire. The idea of verbatim publication has been wisely given up, except in a few extraordinary cases of great importance and limited length. The publication of the Jugements et Délibérations du Conseil Souverain did not justify the nearly 
eighty thousand dollars spent on the first six volumes. After this the work was stopped at the year 1716. The money could be put to far greater use by making one or more facsimiles and by extending Mr. Roy's system of Inventaires to every important collection, public or private, that has no such thing of its own.

The present importance and future significance of Mr. Roy's Inventaires lie in the fact that they are the first descriptive catalogues of Quebec Provincial Archives begutn as the first step towards the complete catalogue of which we have just been speaking. There have been other good catalogues: witness, Mr. E. Z. Massicotte's Répertoire des Arrêts, Edits, Mandements, Ordonnances et Règlements conservés dans les Archives du Palais de Justice de Montréal, $1640-1760$. There have also been many good volumes of extracts or verbatim documents published by the Dominion, the province, societies, and individuals. But Mr. Roy's Inventaires are the first promise of what, if carried out in its entirety, will be the single master-key to all the archives of or in any way concerning the province of Quebec. They must, of course, be supplemented by the guides to which we have referred so often: one guidebook giving general references to all provincial archives which have their own Inventaires; and any other giving still more general references to all the archives that correlate Quebec with the rest of Canada as well as with its French and British fatherlands.

Mr. Roy's nine published volumes of Quebec archival Inventaires are simply "ouvrages honorés d'une souscription du Gouvernement de Québec," because they were all undertaken before he had been transferred from the Quebec part of the Dominion Archives to the sole charge of the new Provincial Branch in September, 1920. His remaining Inventaires will be published as regular provincial bluebooks. The whole thirty or so will then form the pregnant nucleus round which the entire provincial Inventaires and guides will grow. The present series, as we have seen before, has the general title of Archives de la Province de Québec. The first nine volumes are uniform in size $\left(10 \frac{1}{2} \times 7\right)$ and general appearance. They are all admirably printed by La Compagnie de 1' Eclaireur, Beauceville, P. Q. And only the dates and special titles differ. The first two volumes were published in 1917 under the special title of Inventaire d'une Collection de Pièces Judiciaires, Notariales, $\mathcal{E}^{\circ} \mathrm{c}$., $\mathcal{E}^{\circ} \mathrm{c}$., conservées aux Archives Judiciaires de Québec. Then, in 1919, came four vol- 
umes called Inventaire des Ordonnances des Intendants de la Nouvelle-France conservées aux Archives Provinciales de Québec. In 1920 came two volumes of Lettres de Noblesse, Généalogies, Erections de Comtés et Baronnies insinuées par le Conseil Souverain de la Nouvelle-France. In 1921 we have a single volume: Inventaire des Insinuations du Conseil Souverain de la Nouvelle-France.

We shall now take them all together, as the unconscious selfrevelation of certain aspects of French and French-Canadian life under the Old Régime, marking the particular collection (with its volume and page) in every case as follows: (JN) indicates the Pièces Judiciaires, Notariales, etc.; (OI) the Ordonnances des Intendants; (LN) the Lettres de Noblesse; and (CS) the Conseil Souverain.

A word about the language might not be amiss to start with, because a study of the seventeenth century documents gives the clue to so much that now seems strange in the French-Canadian ways of speaking French. The speech of New France (and of Quebec to-day) of course followed the universal principles of evolution in remaining comparatively fixed among those that used it in a remote and simple community, while the French spoken in the Mother Country changed much more rapidly in response to the ways of a far more complex life. The same is equally true of all other oversea communities of a similar kind. The language of New England is still, in some ways, older than that of old England to-day; and there is more of the old WestCountry speech alive in parts of Newfoundland now than in Devonshire itself. People who wonder why French Canadians say Franças instead of Français might like to know that the old French Army rhyme set to the dinner call known as La Soupe runs thus:

C'est pas d'la soup', c'est du rata;

C'est assez bon pour le soldat,

Pour le soldat fran'ça's-

And perhaps they might remember that just about the same time as the French of France were still calling themselves franças Alexander Pope was amusing the Augustan English with this famous (or notorious) couplet:

And thou, great Anna, whom three Realms obey,

Dost sometimes counsel take, and sometimes tea.

We might begin picking out characteristic bits almost anywhere in Mr. Roy's most interesting volumes. But we may as well 
make some attempt to proceed decently and in order by beginning with the source of all authority in France, taking up, first, Jurisdiction, then Lettres de Cachet, and so on. And here we must offer, for what it may be worth, the only adverse criticism we can manage to scrape up against Mr. Roy. The Ordonnances des Intendants are only complete from 1705 . Those of the previous forty years are scattered about piecemeal in different collection's, and suffer from many gaps. But is it not just a little meticulous of Mr. Roy to begin with 1705 and ignore 1665 till more than half way through Volume III?

JuRISDICTION. The Ordonnance pour la levée des Dîmes et l'Entretien des Curés en Canada (OI, iii, 246), promulgated on August 23, 1667, begins with reciting the commissions of Tracy, Courcelles, and Talon. "Alexandre de Prouville, Chevalier Seigneur de Tracy, Conseiller du Roy en ses Conseils, Lieutenantgénéral des armées de Sa Majesté et dans les Isles et terre firme de l'Amérique méridionale et septentrionale, tant par mer que par terre . . . . Daniel de Rémy, Seigneur de Courcelle, Conseiller du Roy en ses Conseils, Lieutenant-général et gouverneur de Canada, Acadie, et Isle de Terre Neuve. . . . . Jean Talon, aussy Conseiller de Sa Majesté en ses Conseils, Intiendant de justice, police et finances de la Nouvelle-France." An ordinance of the previous 9th of September (OI, iii, 225) is worth study as it gives the king's answers to M. Le Barroys, "Agent-Général de la Compagnie des Indes Occidentales," touching the relations of this company to the Crown and its representatives in Canada. Senator Chapais's excellent preface (OI, i, iii) gives a very succinct description of the intendant. "Le gouverneur et l'évêque seuls étaient au-dessus de lui. Il présidait au Conseil Supérieur. Il poûvait juger souverainement en matières civiles. Tout ce qui concernait la direction, le maniement, et la distribution des deniers royaux, et aussi des vivres, les munitions, les réparations, les fortifications, les contributions, la voirie, le commerce, etc., étaient de son ressort. Ses vastes attributions faisaient de lui la cheville ouvrière de notre système gouvernemental. On ne saurait écrire l'histoire économique et administrative de la Nouvelle-France sans recourir. . . . aux ordonnances. . . . des intendants." The governor could report to the king without the consent, or even the knowledge, of the intendant; while the intendant had to report through, or concurrently with, the governor. But there was nothing to prevent the intendant from reaching the king's 'ear by private means; and little to check him in 
Canada when he had a stronger will and less scrupulous character than the governor's. We all know what happened in the last sad days under Bigot and Vaudreuil, who together made the great Montcalm's naturally difficult position simply impossible. The root trouble in time of war was division of command, civilian interference at every turn, overlapping authority, and all the evils of the autocratic system without any of its advantages, owing to the absence of any autocrat on the spot. The system of intendants worked better in France, where they were in close touch with the king, helping him, in accordance with the principles of their inventor, Richelieu, to make all parts and parties work together in spite of local obstacles. Far off in Canada it was apt to be a different story; and continual admonitions were required to readjust from France the respective functions of these two prime officials: for instance, on April 10, 1684 (CS, 96), “Difficultés qu'il plaira à monsieur le marquis de Seignelay de décider sur les fonctions du gouverneur et de l'intendant du Canada. Ces difficultés sont au nombre de dix et ont rapport aux déserteurs français, aux congés pour aller en traite, aux établissements nouveaux, aux concessions à accorder, aux sauvages; aux gouverneurs particuliers de Montréal, des Trois-Rivières et de l'Acadie, aux cas d'amirauté à la juridiction de l'intendant . ."

LETTRES DE CACHET generally seem to suggest the Bastille, if not extinction in an oubliette. But they were of milder general use than that; and even full of paternal benevolence towards scape-grace members of great families who had to leave their country for their country's good, with the hope that they would do better for themselves and for society in the adventurous wilds of Canada. When a scape-grace was sent out, a lettre de cachet would also be sent, asking the Canadian authorities to keep their eye on him, partly with a view to his own good, and partly to prevent his wandering off among les Anglais to the south, and perhaps taking ship for France again: e.g. (OI, ii, 201), “. . . . défense à toutes personnes venues en ce pays par lettres de cachet d'en sortir. . . . à peine. . . de trois mois de prison pour la première fois et de peine corporelle en cas de récidive."

THE KING occasionally sent a personal message to his faithful Canadians, usually on the declaration of war, the conclusion of peace, or an important event in the royal family, such as his own marriage (CS, 177: September 5, 1725) with the "princesse Marie" whom his (Louis XV's) "oncle le duc d'Orléans a épousée en mon nom dans ma ville de Strasbourg. C'est pourquoy j'écris 
au sieur évesque de Québec de faire chanter le Te Deum et pour vous dire d'y assister et d'y faire aussy assister le Conseil Supérieur, que vous fassiez enisuite allumer des feux de joie, tirer le canon et donner les marques de réjouissance accoutumées . . je prie Dieu qu'il vous ayt, monsieur le marquis de Vaudreuil, en sa sainte garde. LouIs."

WaR does not figure largely in these volumes devoted mostly to civil government and legal affairs. On November 15, 1709 (OI, i, 89), the "habitants du gouvernement de Montréal" were ordered to bring "la pierre et la chaux nécessaires pour la bâtisse en pierre du fort de Chambly," as well as other materials. It must be remembered that supply and transport, ordnance stores, the materials for military works, etc., were under the intendant. On May 30, 1711, there was passed an "Ordonnance qui fait défense aux prisonniers anglais qui sont dans la ville de Québec de s'attrouper tant dans les rues que dans les maisons, de sortir des maisons de leurs maîtres après le soleil couché, de fumer ou porter du feu dans les rues, le tout à peine d'être mis dans les cachots et de 50 livres d'amende contre ceux qui les retireront chez eux ou leur donneront à boire ou à fumer." English readers will remember that Bishop St. Vallier of Quebec was then a prisoner of war in the Tower of London, where he became quite a social lion. Under date of April 16, 1672 (CS, 25), we find the "Déclaration de guerre contre les Etats-Généraux des Provinces Unies des Pays-Bas." The signing of the momentous Treaty of Utrecht is also duly entered (CS, 249).

THE NAvy is not forgotten. We learn (OI, iii, 261) that manof-war oak, as well as other wood "propres à la construction de vaisseaux," was watched with a careful eye from an early period; while the following (OI, ii, 289: March 20, 1740) shows that this vigilance was renewed from time to time: "Ordonnance qui défend aux propriétaires des terres de l'île Jésus et ses seigneuries du Lac-des-Deux-Montagnes, d'Argenteuil, de Vaudreuil, et de l'île Bizard d'y couper ni faire couper aúcuns chênes jusqu'à ce que l'intendant les ait fait visiter et marquer afin de retenir les chênes propres à la construction des vaisseaux de Sa Majesté." The Pièces Judiciales, Notariales, etc., come down to the nineteenth century, when, in 1801, an entry was made (JN, 400) about ' "l' Elizabeth saisi et pris par la Résistance, vaisseau de guerre anglais". Prizes from les Anglais appear earlier (JN, 26 and 32, in 1691 and 1698).

ShIPPING figures much more largely. Here (JN, I, i: May 3, 
1642) are orders for a living lighthouse: "aux sieurs Marsollet et Pierre de Launday, commis de MM. de la Compagnie de la Nouvelle-France, de se rendre vers la Pointe aux Alouettes et d'y demeurer jusqu'au ler juillet pour faire garde et découvrir les navires et autres vaisseaux qui pourraient venir en ces quartiers afin de l'en avertir le plus diligemment possible." Wreck enquiries frequently occur (JN, i, 24: June, 1688). So do questions of average $(\mathrm{JN}, \mathrm{i}, 151$, etc.). The man who called his vessel L'Infortuné ( $\mathrm{JN}, 351$ : in 1757) deserved to get in'to trouble. An early entry about navigation on the Great Lakes is that of October 31, 1680 (OI, iii, 281), giving permission to "François Pollet, marchand, de Paris, de faire construire à ses dépens une barque au Fort Frontenac." A crew is ordered not to quit a salvageable wreck (OI, ii, 304). People living below Quebec are forbidden to board incoming vessels (OI, iii, 73). Masters are ordered to declare their cargoes within twenty-four hours (OI, iii, 161). And landsmen are ordered to "buoy" (baliser) the winter roads (OI, i, 9). French-Canadian French is still full of nautical terms. You steer your course about the country by the points of the compass. If you miss the channel buoyed out for you in winter through the snow you will founder (caler) and perhaps become dégradé, like a derelict. You must embarquer into and débarquer out of a vehicle of any kind. A well-dressed woman is said to be bi'n gré-yée, that is, quite fit to go foreign. Horses are moored (amarrés), enemies reconciled by being $r a$ marrés, and winter heralded by a broadside of snow on the 25th of November-la bordée de la Ste. Cathérine.

Appointments in Canada required certificates of vie et moeurs (JN, 193, etc.). Précédence was'a subject of mưch concern to all parties, especially precedence in church ( $\mathrm{JN}, 91$, etc. and $\mathrm{OI}$, ii, 297 , etc.). Such precedence depended on official, not nobiliary, rank.

NoBLESSE is the subject of two volumes (LN) which should go far towards correcting the usual mistakes about the so-called Canadian nobility. As a matter of fact, apart from the barony of Longueuil, now recognized by the British Crown, there never was any real landed nobility in Canada of the same kind as the great landed nobility of France. Moreover, the many noblemen who at different times came out to Canada nearly all went home again. The seigneurs resident in Canada formed a latided gentry or squirearchy, a sort of petite noblesse. But there never was any haute noblesse rooted in the soil. Mr. Roy's own preface explains 
the whole case. His two volumes form a kind of biographical Burke. Names and signatures of the old régime are very puzzling without a key. The head of the family signed the family name alone. Other members used their Christian names with that of their estate, if they had one. If they had no estate, they simply used the Christian and family names with a de between them. One of the curiosities of the times was the co-existence of three "marquis de Vaudreuil", all signing simply Vaudreuil, though two must assuredly have had no such right whatever, as there was only one marquisate. Canada never seems to have had any "Commissaire nommé par le roi pour la recherche des faux nobles."

Though there was no haute noblesse there were many scions of very ancient families; and it should be borne in mind that many an untitled man is of infinitely more aristocratic antecedents than some newly titled people are. Mr. Roy's Lettres de Noblesse have another charm in the mere names of certain men or places, names which alone can conjure up a vision of the old régime. Does not la Baronnie des Islets remind one of that glorious appellation now merged in the minor titles of the Heir to the British Thronethe Lord of the Isles? And is there not something of "that other harmony of prose" about Lafontaine de Belcour, Le Gardeur de Repentigny, Le Moyne de Châteauguay, Chartier de Lotbinière, Arnolet de Rochefontaine, and Marie-Madeleine de Verchères?

SEIGNiories and SETtLement naturally fill many entries. The seigniorial system was no bad way of settling a new country exposed to Indian raids and intercolonial wars. The harsher feudal features were omitted or softened down; and even the corvées and seigniorial dues, with all their imperfections, worked pretty well throughout the seventeenth and eighteenth centuries. The fact that seigniories became anachronistic in the nineteenth century does not disprove their comparative success in earlier times, that is, of course, considering the peculiar conditions then obtaining. The Ordonnance pour la Confection du Papier Terrier de la Terre et Seigneurie de Montréal (OI, iii, 240: November 1, 1666) is a good specimen document beginning "Monseigneur l'Intendant, supplie humblement Gilles Perot, prestre," on behalf of "Alexandre Le Rageois de Bretonvilliers, Prestre Supérieur du Séminaire de St. Sulpice, seigneur de la d. Isle de Montréal," and ending with Talon's approval: "Soient les vassaux, censiers, tenanciers, et autres redevables. . . . assignés par affiches publiques, pr. proceder sur les fins de la presente requeste . . ." The nomenclature is redolent of life on the old concessions; and 
much of it lives on in modern documents, though things themselves have changed. Open almost anywhere at random (e.g., OI, ii, 40; November 4, 1729), and note how the "commissaire du Grand Voyer décide qu'un chemin qui montera droit du quatrième rang de la seigneurie de Maure au chemin royal de la côte Saint-Ange . . . "; or (OI, ii, 217 : November 10, 1735) where the "habitants de la seigneurie de la Pocatière" are ordered to pay arrears to "leur seigneur, le sieur d'Auteuil," including "les cens, rentes, et lods et ventes." The seigneurs, in their turn (CS, 41: May 29, 1673), though enjoying their rights over "les dites terres à perpétuité en tout droit de fief et seigneurie portant la foi et hommage au château de Québec, suivant la coutume de la Prévôté et Vicomté de Paris," had to do their duty to the state in peace and war.

Concessions were of all sizes and many kinds. See (CS, 33: May 13, 1675) "Concession par Sa Majesté à Robert Cavelier de la Salle . . . du dict fort, appelé de Frontenac, et quatre lieues de pays adjacent, à compter deux mil toises pour chacune lieue le long des lacs et rivières au-dessus et audessous du dit fort, et d'une demie lieue, ou mil toises, au-dedans des terres, les isles nommées Gan8nk8esnot et Ka8enesgo et les isles adjacentes, avec le droit de chasse et de pesche dans le dict lac Ontario et rivières circonvoisives, le tout en tiltre de fief et en toute seigneurie et justice . . . . " Smaller men had smaller lands and smaller rights, like "Jacques de la Mothe, marchand, étant à présent en la ville de Paris," who got only "dix arpent's en l'île d'Orléans"' (JN, i, 6-7: March 22, 1661).

Other typical entries relating to settlement are: (OI, ii, 24) the corvées required then, instead of municipal taxation now; (OI, iii, 271-3) the report required in 1672 from "tous ceux qui ont reçu plus de quatre arpents . . . . d'indiquer la quantité et la qualité des terres possédées, défrichées et non défrichées"; the regulations (OI, iii, 286: April 28, 1685) permitting soldiers to "travailler chez les habitants; défense aux dits soldats de travailler avec leurs uniformes, et défense aux habitants de payer aux dits soldats plus de dix ou douze livres par mois"; the survey (OI, ii, 96) of lands; prospecting for lead (OI, ii, 176); gathering pitch (OI, ii, 184); and explơring new country (OI, ii, 256).

THE LAW followed the progress of settlement to the best of its ability. Thieft opens the record (JN, i, 1) on December 13, 1638 , when nine men stole some boards from no less a personnage than Jean-Baptiste Le Gardeur de Repentigny. Next comes "Chicane de voisins" (JN, i, 1, March 9, 1642). It is not till 1671 
that we rise to the height of murder ( $\mathrm{JN}, \mathrm{i}, 11$ ), nor till 1690 that we find a "procès criminel contre le cadavre du nommé Saint-Germain, soldat de la compagnie de La Groix, accusé de s'être étranglé dans son cachot" (JN, i, 25). Meanwhile the seventeenth century equivalent of "Please, Sir, he's got my rifle" appears in the "Plainte d'Oliver Chotart contre François Boivin à propos d'une arquebuse" (JN, i, 3: May 20, 1647). In 1739 $(\mathrm{JN}, \mathrm{i}, 112)$ a merchant and an officer of French-Canadian regulars have "Chicane à propos d'une partie de billard." Three years later "Edouard Hamilton, irlandais de nation", gets into trouble with "Ignace Gamelin, des Forges Saint-Maurice" (JN, i, 120). In $1740(\mathrm{JN}, \mathrm{i}, 113)$ there is a case in the Court of Admiralty against the "fermier des traites à Tadoussac à propos d'une baleine trouvée par des sauvages à Manicouagan." In $1745(\mathrm{JN}, \mathrm{i}, 128)$ "Michel Senneville de Bussy, soldat de la garnison de Montréal" actually had the temerity to "fabriquer des ordonnances."

Sexual troubles appear (JN, i, 14) in 1673 , when Jeanne Poireaư "déclare qu'elle ne peut plus supporter les mauvais traitements qu'elle reçoit de son mari, ni ses débauches continuelles." In 1732 ( $\mathrm{JN}, \mathrm{i}, 89$ ) the king himself thunders forth an edict against the concealment of births. Illegitimacy does not appear with undue frequency; and it seems to have been sensibly dealt with. In 1735 (OI, ii, 191) Jean Pepin had to pay MarieMadeleine Desrochers "cinquante livres de provision alimentaire pour servir aux frais de gesine et en outre se charger de la nourriture et entretien de l'enfant qui naîtra d'elle, et apporter tous les trois mois au procureur du roi un certificat de l'état du dit enfant, et jusqu' à ce que le dit Pepin ait satisfait au paiement de la somme de cinquante livres il gardera prison." In 1739 Louis Briquet, dit Lefèbvre, was finally brought to book, after having escaped the just vengeance of a widow for more than a year (OI, ii, 292). He then had to "payer une nourrice, puis nourrir et élever la dite fille dans la religion catholique, apostolique, et romaine, jusqu'à l'âge de dix-huit ans."

In $1704(\mathrm{JN}, \mathrm{i}, 295)$ the minor children of the late Jean Le Picard had to have a new tutar to replace M. Fromage, "qui s'est embarqué pour le voyage de la filibustre." On September 20, 1663 , it required the intervention of the Sovereign Council to appoint Jean Gloria first Notary Royal of Quebec "après deüe information faicte de ses vie, moeurs, religion catholique, apostolique, et romaine." Thus began a vast mass of documents redolent of the good old Law-French phraseology, full of the settled places 
in Canada proper, where you could "tenir feu et lieu," of references to that "Coutume de Paris" which is still quoted in Quebec courts, and to "les pays d'en haut" which only adventurers and missionaries had ever seen when Gloria first handled the notarial pen.

Defamation has its usual place. In 1727 (OI, ii, 17) MarieThérèse Houymet not only had to pay Marie-Madeleine Roullois twenty livres but give her "un acte par écrit par lequel elle la reconnaît pour fille de bien et d'honneur non tachée." In 1707 (OI, i, 41) "la fille Poitras, dont le commerce scandaleux avec le sieur Delorme continue depuis langtemps", was ordered back to her father, who was ordered to receive her, while Delorme was forbidden to keep her and she to stay with him. At the same time the "sieur Martin, curé de Sainte-Foy," was permitted to remove her from the bad house to the good in case of her contumacy, while naughty Delorme had to pay her board until such time as the court saw fit to make him marry her. Blasphemy, sometimes indistinguishable from common swearing, excited the wrath of the authorities from a very early date. In 1665 (OI, iii, 218) Jacques Bigeon had to pay "dix livres pour avoir juré et blasphemé" and remember that if he dared to "récidiver" he would suffer "punition corporelle." Arson raised a tremendous hue and cry in 1734 after "un nommé Thibault, grandement soupçonné, avec la négresse de la veuve Francheville, d'avoir allumé le grand incendie qui a dévasté Montréal le 10 avril dernier." On October 1, 1749 (JN, ii, 359), two great characters in the romance of the Chien d'Or step into real life "au sujet de la grâce du sieur de Repentigny, assassin du sieur Philibert". And is there not some pathos, mixed of course with bathos, in the final entries made in the solemn tomes of the Old Régime, about the little things of daily life, when the world they had so long and faithfully recorded was crumbling into the dust of death? On July 8, 1758, the day that master-strategist, Montcalm, fought so well at Carillon (Ticonderoga), the intendant Bigot was appointing (OI, iii, 210) "Jacqu'es Gouget huissier à la place de Ferdinand Lebrun." And in the fatal 1760 (OI, iii, 212) Repentigny makes his final appearance in a squabble with Joseph Duprat over a stable and a barn.

Municipal Regulations of all kinds constantly appear in the ordonnances: Building regulations (OI, iii, 288), orders about stray pigs (OI, iii, 294), garbage (OI, i, 112), the numbers to be borne on vehicles (OI, ii, 9 ), orders regarding the drain for which 
the Hôtel-Dieu was responsible (OI, ii, 33), the very primitive fire brigade of Quebec (OI, ii, 208), and the heinous offence of making home-brewed ale in your own back-yard (OI, iii, 185). DRINK was repeatedly regulated; though more with regard to trade with the Indians than among the whites at home. One regulation (OI, ii, 6 and 7 ) put bars out of bounds for soldiers and out of bounds for everybody during divine service. Another (OI, ii, 217) forbade serving those who were already drunk; a third (OI, iii, 48) allowed drink to be given only to those that "needed it"; and a fourth (OI, iii, 49) was an ordonnance "qui défend à toutes personnes de donner à boire aux matelots de l'équipage du vaisseau du Roi $l e$ 'Rubis qui sont à Hôtel-Dieu de Québec et commencent à se mieux porter." DocroRs engaged the attention of the Sovereign Council as early as 1651 (CS, 6), when Jean Madry was made barber-surgeon of Quebec as "lieutenant et commis" of no less a personage than "François de Barnoin, conseiller du roi, son premier barbier et chirurgien ordinaire de Sa Majesté." Canadian doctors were protected in 1710 (OI, i, 105) against interloping ships' surgeons, and in 1731 (OI, ii, 89) "le nommé Mas du Passage" was ordered to pay "au sieur Bertier, chirurgien du roi entretenu en ce pays, la somme de vingt-quatre livres pour pansements faits à leur fille blessée dangereusement à la tête par un coup de pied de cheval."

FOOD CONTROL, of which present-day Europe knows so much and even America a little, was a pathetic necessity in May, 1667 (OI, iii, 243), when the starving colonists were forbidden "d'enlever aucun grain semé, de joùr ou de nuit; les propriétaires pourront cependant en cueillir avant la maturité à cause de la disette, mais en plein jour." But the sinister figure of Bigot had more than even the war to do with food control from 1755 to 1760 , when one ordonnance followed another in rapid succession (OI, iii, 193, 200, 209, etc.).

FISH and GAME were plentiful in early days simply because white men were not. In the seventeenth century the hunters were apt to become the hunted if they went too far afield among the Indians; so in 1678 we find one of several orders issued by the Sovereign Council (CS, 40) against going beyond the "terres défrichées et une lieue à la ronde, à la peine de deux mille livres d'amende." Fur, fish, and game reserves were often granted for a term of years, $e$. g. in 1738 (CS, 234-5) to "Jean-Baptiste Pommereau . . . cinq lieues de front à la côte du Labrador depuis la pointe du gros Mecatinat . . . avec le privilège d'y faire, 
à l'exclusion de tous autres, la pêche du loup marin, chass $\epsilon$, et traitte avec les Sauvages pour dix années." The intendant (OI, ii, 257: in 1738) then turned his paternal eye on "le dit Pommereau," warning him "de ne débaucher directement ni indirectement les sauvages dépendants du poste de Mingan exploité par le sieur Volant d'Haudebourg." Interest in porpoises exceeded that in seals, the latter not being fur seals, while the former were really the little white whale from which much oil and "porpoise hide" could be obtained!. In 1707 "une société sur la rivière Ouelle" was authorized "pour faire la pêche des marsouins" near the place known to modern summer visitors as the one where you take the ferry for Murray Bay. Game laws, more honoured in the breach than the observance, were promulgated from time to time. In 1727 (OI, i, 296) the close season for the Canadian "partridge" was fixed from mid-March to midJuly, with "cinquante livres d'amende"; while Pierre Poulin and Étienne Morel, of the famous Sainte-Anne-de-Beaupré, were guaranteed in their rights against "toutes personnes" who had the audacity "de toucher à la chasse" thereabouts, "sous peine de dix livres d'amende envers le roi et de restitution du double de la valeur envers les dits Poulin et Morel."

BUSINESS QUestions occupy a good many of Mr. Roy's archives, such affairs being then "controlled" at all times in much the same way as they were in the worst areas during the recent War. Regulations about apprentices (JN, 12), the seizure of contraband furs $(\mathrm{JN}, 13)$, and ferry services $(\mathrm{JN}, 96)$ were of the normal kind. But the Ordonnance of 1671 "contre le meunier de la Touche-Champlain, quii, au mépris d'une ordonnance précédente, vend le ble cent sols le minot" has the true smack of profiteering. In 1707 (OI, i, 25) five tanners were licensed for Qu'ebec with the solemn warning not to expose for sale any leather not up to standard. One of them rejoiced in the name of Larchevêque, another in that of Dedieu. In 1709 (OI, $i, 80)$ "chaque habitant des côtes du gouvernement de Montréal ne pourra avoir plus de deux chevaux ou cavales et un poulain." An ordinance of 1727 (OI, ii, 24) "fait défense aux habitants, meưniers, et autres de livrer leurs farines, pois, et autres grains autrement que dans des sacs; seuls, les marchands et négociants mettroǹt les farines et grains dans des quarts, barriques, et futailles, qui devront être neuves, de bonne qualité, et marqués d'une marque particulière." The exasperating system of going shares in every individual item, dead or alive, is the subject of several fulminations. 
One of these (OI, ii, 56: of 1730) "condamne Charles Campagna à fournir à son voisin Asselin la moitié du harnais qui leur appartient en commun, c'est-à-dire un boeuf et un cheval, pour être employés pendant quatre journées entières aux labeurs et travaux de la terre du dit Asselin: défense aux dits Campagna et Asselin d'user l'un envers l'autre d'aucunes voies de fait et mauvais procédés." Standard weights and measures are insisted on $(\mathrm{OI}, \mathrm{ii}, 129)$ in 1732 , when "tous marchands, négociants, boulangers, bouchers, cabaretiers, regrattiers, et toutes autres personnes qui se mêlent de commerce" have to bring their "aulnes, poids, et mesures pour être vérifiés sur les étalons déposés au dit greffe et y être marqués d'une fleur de lys." Protection against foreign goods required the august intervention of the Sovereign Council. For instance, in 1709 (CS, 117), "Edit de Sa Majesté qui porte défense de faire commerce et le transport du castor chez les habitants des colonies anglaises au préjudice des intérressés en la Compagnie des Castors." Again, in 1716 (CS, 137), "Sa Majesté, ayant esté informé qu'il se vend des marchandises de fabrique étrangère, ce qui cause un grand préjudice aux manufactures de son royaume . . . fait très expresses inhibitions et défenses" in the best style of the colonial system then followed by every country that had any colonies at all.

MONEY and Prices exercize official vigilance at every turn. Card money (OI, iii, 287) required in 1686 the usual threats of "150 livres d'amende" to get it into circulation among a people who in many places, within living memory, had no faith in anything but l'argent dur. Currency questions were what Dr. Johnson would have called as anfractuous as ever in 1690 (OI, iii, 289), when the intendant "fixe de nouveau le cours des louis d'or, des demi-louis", and so on down the long and fluctuating line. In $1705(\mathrm{OI}, \mathrm{i}, 1)$ it was ordered that in future "les droits d'entrée sur l'eau-de-vie, les vins et le tabac seront payés en monnaie de France." In 1723 (OI, i, 249), it was ordained that "tous les castors qui seront livrés à Montréal [where the name of Beaver Hall Hill preserves the memory of the Fur Lords under the British régime] après le dernier jour de septembre ne seront payés que l'année suivante en lettres de change sur France"-which reminds one of the old Hudson's Bay pound notes payable at twelve months on the Company's account in London. Students of economics-and toutes autres personnes too; for who isn't interested in the cost of living now?-will find many tit-bits of information in reference to prices. One document (OI, iii, 293) gives the price 
of meat in 1701 as "cinq soưs la livre, de Pâques à la Saint-Michel au carême à causse de la guerre." Another (OI, i, 33: in 1707) gives hide prices as follows: "peau de boeuf neuf livres, celle de vache six livres quinze sols, celle de veau douze sols." The price of meat in 1748 (OI, iii, 113) was "le veau cinq sols la livre et le mouton quatre sols." When Bigot and Cadet began operating the market ("Joseph Cadet seul, à l'exclusion de tous autres") "la viande de boucherie" was "trois sols six deniers la livre" (OI, iii, 137); but it soon went up, till, at the end of their nefarious reign, it stood at famine prices, when obtainable at all. Land values varied greatly. But it must be remembered that fiefs were different from the tenures of tor-day. In 1730 (OI, ii, 80) the price "d'un fief sis à Chambly consistant en une demi-lieue de front sur une lieue de profondeur" was "3240 livres." Imagination fails to grasp an adequate idea of the "petite maison de bois" which "Lagneau, dit Poitevin, soldat," bought in 1727 (OI, ii, 4) from "Rhéaume, charretier" for "vingt-quatre livres." A very different kind of property-slaves - is duly mentioned here and there; with humane suggestion in 1736 (OI, ii, 209), when "tous les particuliers de ce pays qui voudront affranchir leurs esclaves seront tenus de le faire par un acte passé devant notaire."

INDIANS, and especially the trade with them, appear again and again. The first "Requête des habitants des Trois-Rivières au Conseil" in 1647 (JN, 3) "s'agit de la traite avec les sauvages." In 1705 (OI, i, 17) "les habitants de Notre-Dame des Neiges, en l'île de Montréal" are warned that "leurs terres seront confisquées s'ils donnent de l'eau-de-vie aux sauvages." In 1707 (OI, i, 32) fines and confiscations are threatened for all who trade "en aucuns autres endroits que dans les villes de Québec, Villemarie, et TroisRivières." In 1746 (OI, iii, 81) muskets, powder, lead, "et autres effets qui peuvent être nécessaires poưr le service du Roi" are put under special ban as goods for the truck trade. An amusing entry (CS, 113) in the Insinuations for 1705 shows the Sovereign Council vainly trying to get the Indian place-names into official French with a liberal use of the letter 8. "La rivière Chach8mayk8sispy" must have puzzled the clerk who had to read the minutes.

VAGABONDAGE is a convenient term to cover everything that the authorities considered absence without leave. In 1678-9 (OI, iii, 280) the prohibition had to be renewed against going "à la traite dans les habitations des sauvages et dans les profondeurs des bois"; and while the second ordonnance "commet le 
sieur Migeon de Branssat pour informer contre les personnes qui retirent les coureurs des bois et les favorisent en leur fournissant des marchandises." Then in 1681 (CS, 48) the king himself sent "Lettres d'amnistie pour les coureurs de bois qui ont fait commerce sans permission." But whether the wind of governmental doctrine blew hot or cold the coureur de bois remained a vagabond. Going to the south "à Manatte, Orange, et autres lieux appartenants aux Anglais et Hollandais" was considered infinitely worse. The Sovereign Council in 1684 (CS, 57) promulgated an "Edit de Sa Majesté pour la punition des Français . . . . qui comme chefs auront enterpris de déserter et se retirer chez les dits Anglais et Hollandais soient condamnés à mort, et à l'égard de ceux qui auront suivy les dits chefs soient condamnés aux galères à perpetuité." Nevertheless the intendants had to keep up a running fire of ordonnances about evasive trading with "Orange, Manatte, Boston, et autres lieux." In 1716 (OI, i, 160-1) the penalty was "deux mille livres pour la première fois et punition corporelle en cas de récidive." By 1732 the fine had been reduced to "cinq cents livres pour avoir été à Sarasto, Orange, La Menade, et Boston sans permission," and there was no mention of corporal punishment "en cas de récidive."

The Naturalization of foreigners was not very common, but commoner than many suppose. The "Brevet de naturalité pour le sieur Feltz, allemand, chirurgien-major des troupes au Canada" (CS, 278: February 3, 1758) is interesting when we remember that this was in the middle of the Seven Years' War. Five years earlier (CS, 265) "Claude Thomas, anglais, établi au Canada depuis quarante-cinq ans" (and, like Feltz and all those who were naturalized in 1710 professing "la religion catholique, apostolique, et romaine") gives as one of his many reasons the fact that twentytwo of his children were all "établis dans la d. colonie." The $\mathbf{1 7 1 0}$ lot fills nearly three of Mr. Roy's big pages, and probably was the greatest single haul New France ever made from New England and its Mother Country. There is what Mrs. Malaprop would have called "a nice derangement of epitaphs" in the spelling of the English and Irish surnames: witness, among the Irish, Jean Lara, Jean-Baptiste Ohé, and Jean-Baptiste Lorcol; and among the English, Scavlor, St. Oburn, Sloutz, 8tozer, Stobberer, Shrurer, Ohr, Goffurier, Tarbol, Fuin, and Furie. The reason probably is that, in those illiterate days, most of the English-speaking people naturalized in Canada had lived there long enough to forget even the proper sound of names they never knew how to spell. 
THE CHURCH-catholique, apostolique et romaine-appears in these volumes only as one among the many other factors that made up the curious problem of New France. The Church's own archives deserve a separate study of their own, for no one can understand Quebec without understanding her FrenchCanadian children's real connection with their Mother Church. Here we need only end an article which has already passed its proper limits by noting a few typical entries which show how Church influence permeated the layman's life in the times which Mr. Roy's revealing volumes bring so vividly before us.

The French-Canadian bishop took the following oath of allegiance to the Crown of France (CS, 233: of 1741): "Sire, Je Henry Marie DuBreuil de Pontbriand, evesque de Québec, jure le très Saint et Sacré nom de Dieu, et promets à Votre Majesté que je luy seray tant que je vivray fidel sujet et serviteur. . . . ." But, from Laval's day to our own, the French-Canadian clergy have been Ultramontane through and through. Gallicanism, discouraged under the French régime, never revived under the British, during which the French Revolution and all that followed tended still more to make Quebec derive from Rome direct, and not by way of France.

Church and State sometimes fell out: witness (CS, 6 et seqq., 15-16; OI, iii, 221 et seqq., etc.) the troubles raised in 1664 by "M. de Mézy, lieutenant-général et gouverneurr de la NouvelleFrance," when he said that "les sieurs de Villeray et Dauteuil nommés pour conseillers et le sieur Bourdon pour prącureur du Roy, à la persuasion dv dict sieur de Pétrée [Bishop Laval] qui les connaissait, et entièrement ses créatures," were foisted on New France against the interests of the king and the public by Laval, etc., etc. Laval wished to make an attempt to settle matters quietly. But Mézy insisted that his ordonnance should be "lüe, publiêe, et affichée au son du tambour aux lieux accoutumés de ce pays." Next year (1665) Mézy stuck to his point in a letter to Tracy, who was coming out as the king's personal representative in all French America. Mézy was then a rapidly dying man. But he forgot none of the troubles "de ce qui s'est passé entre $M$. l'Evesque de Pétrée, les Pères Jezuittes et moy" (CS, 15). He ends with a little human touch (CS, 16): "Vous aurez aussy pour agréable un petit présent quie je vous faicts qui est une petite baricque de vin d'Espagne." The year following (1666) the story of the trouble is told again (OI, iii, 221) from a different point of view in the "Ordonnance de MM. de Tracy, Courcelles et Talon 
sur une requête du Père LeMercier, Supérieur des Jésuites de la Nouvelle-France, au sujet des Choses qui ont été écrites par feu M. de Mézy sur le compte des dits Jésuites." Father LeMercier wielded his caustic pen with such effect (OI, iii, 221-4) that by the end of the same month (May, 1666) the Sovereign Council ordained that all its records concerning the trouble should be immediately "biffés et rayés" for ever.

Orders for corvées to build or repair churches appear in both JN (e.g., 378 and 293) and OI (e.g., ii, 281). "Tous les habitants . . . chacun leur quote-part . . en présence du missionaire, par le capitaine de la côte, le marguilliers, et les deux plus anciens habitants . . ."Mr. Roy's documents come down to the British régime, both before and after the Quebec Act of 1774 . In 1761 ( JN, 392) Murray "ordonne aux habitants de Saint Thqumas de rembourser à leur curé" what had been spent on "travaux faits au presbytère." And in 1791 Dorchester appoints "Adam Mabane, John Fraser, Thomas Dunn, Hertel de Rouville, Pierre Panet, Gabriel-Elzéar Taschereau, et Pierre-Louis Descheneaux, Ecuiers, commissaires en vertu de l'acte concernant la construction et la réparation des églises." Tithes of course frequently occur. An interesting early entry is to be found in the ordonnance of Tracy, Courcelles, and Talon in 1667 (OI, iii, 246), where the following definition is laid down: "toutes les dixmes de quelque nature qu'elles puissent estre . . . se payeront seulement de treize portions une," that is, the "good old rule": "one for the Church and a dozen for yourself."

Daily life had churchly regulations, enforced by the civil power: e.g., one (JN, 10) against eating meat in Lent, another (JN, 64) against holding markets during mass, and others (OI, i, 97; ii, 112; and iii, 1) against bad behaviour of various kinds in or near a church. These three regulations about behaviour are: (1) "Défenses à toutes personnes de causer dans les églises . . . ni de fumer à la porte . . . défense de sartir dans le temps que les curés font leurs prônes . . ." (2) "Très expresses défenses de sortir pendant le service et le prône pour fumer et $c$ : user au scandale des autres paroissiens." (3) "Défense aux habitants de la Nouvelle-France de s'injurier ni de se battre au devant de l'église." 